\title{
Predictive Shear Strength Models for Tropical Lateritic Soils
}

\author{
Oluwapelumi O. Ojuri \\ Department of Civil Engineering, Federal University of Technology, Akure, P.M.B. 704, Ondo State, Akure, Nigeria \\ Correspondence should be addressed to Oluwapelumi O. Ojuri; ojurip@yahoo.com
}

Received 20 October 2012; Revised 24 January 2013; Accepted 24 January 2013

Academic Editor: Guangming Xie

Copyright (C) 2013 Oluwapelumi O. Ojuri. This is an open access article distributed under the Creative Commons Attribution License, which permits unrestricted use, distribution, and reproduction in any medium, provided the original work is properly cited.

\begin{abstract}
This research focused on the indirect determination of soil shear strength using basic soil properties for a lateritic soil area. Samples were collected from six different locations in the Federal University of Technology Akure, Ondo State, Nigeria. These lateritic soils fall within the A-2, A-6, and A-7 groups in the AASHTO classification system. Exploratory analysis of the six independent variables was performed using the statistical analysis of principal components. The stepwise multiple regression was used to establish the best predictive models for the California bearing ratio (CBR) and undrained shear strength $\left(S_{u}\right)$. A remarkable significant model for undrained shear strength $\left[S_{u}=-547.713+0.381 \mathrm{MDD}-9.104 \mathrm{GI}\right]$ with $\left(F_{2,3}=229.476, P<0.005\right.$, Adjusted $R_{2}=0.989$, Std. Error $=7.5638$ ) emerged. This model accounts for $99.4 \%$ of variation in the dependent variable. For the included predictor variables beta $=0.722, P<0.005$ and beta $=-0.417, P<0.005$ for MDD and GI, respectively, where other variables are excluded from the model. This makes a quick evaluation of the shear strength of lateritic soils by using their maximum dry density and group index values possible.
\end{abstract}

\section{Introduction}

The springing up of various building construction projects in many growing urban centres in Nigeria and within the university campus has necessitated a critical examination of the site/soil investigation methods for the purpose of safety and economic sustainability. The attempt of an indirect soil strength test method is borne out of a concern for the reality of scarce functional detailed geotechnical testing facilities in most of our technical/engineering institutions in Nigeria. Procedures that allow the prediction of the shear strength of tropical soils or the minimization of the number of tests or costs needed to measure them are advantageous because of the limited availability of state-of-the art facilities for testing and oftentimes lack of the required degree of expertise, in developing countries. A simplified procedure is proposed in this paper to estimate the shear strength of a tropical soil.

Lateritic soils can be described broadly as all products of tropical weathering with red, reddish brown, or dark brown colour, with or without nodules or concretions, and that generally (but not exclusively) found below hardened ferruginous crusts or hard pan [1]. Numerous studies have been made on the engineering properties and behaviour of laterite soils [2-6]. Several previous studies on laterite soils by Gidigasu [7] for Ghanaian soils, Malomo [8] for Brazilian soils, and Madu [9], Ola [10-12], and Ogunsanwo [13, 14], Malomo [15], Mesida [16] for Nigerian soils have demonstrated the susceptibility of laterite soils to degradation under load. Their soil grains, which are derived from the cementation of smaller ones, break down to smaller sizes on application of load. Fall et al. [17] tested laterites derived from different rock-parents and examined the stress-strain behaviour of the compacted laterite soils. They observed that the moulding moisture content and the confining pressure have little influence on shear strength.

Shear strength forms an important engineering property in the design of numerous geotechnical and geoenvironmental structures such as earth dams, retaining walls, pavements, liners, and covers. Several procedures have been proposed in the literature, to predict the shear strength of an unsaturated soil. These procedures use the soil-water characteristic curve as a tool either directly or indirectly along with the saturated shear strength parameters, cohesion $\left(c^{\prime}\right)$, and angle of internal friction $\left(\phi^{\prime}\right)$, to predict the shear strength function for 
TABLE 1: Summary of geotechnical test results for the six locations.

\begin{tabular}{lcccccccccc}
\hline Sample & $\begin{array}{c}\text { Depth } \\
(\mathrm{m})\end{array}$ & $W_{L}(\%)$ & $W_{p}(\%)$ & $\begin{array}{c}\text { Plasticity index } \\
(\mathrm{PI})\end{array}$ & $\begin{array}{c}\text { Natural moisture } \\
\text { content } \\
(\%)\end{array}$ & $\begin{array}{c}\text { MDD } \\
\left(\mathrm{kg} / \mathrm{m}^{3}\right)\end{array}$ & $\begin{array}{c}\text { OMC } \\
(\%)\end{array}$ & $\begin{array}{c}\text { UCS } \\
(\mathrm{kPa})\end{array}$ & $\begin{array}{c}S_{u} \\
(\mathrm{kPa})\end{array}$ & $\begin{array}{c}\text { CBR value } \\
(\%)\end{array}$ \\
\hline A & 1.5 & 32 & 24 & 8 & 25 & 1652 & 20.6 & 71 & 35.5 & 35 \\
$\mathrm{~B}$ & 1.5 & 36 & 24.1 & 11.9 & 24 & 1742 & 17.8 & 106 & 53 & 45 \\
$\mathrm{C}$ & 1.5 & 48 & 23.9 & 24.1 & 21 & 1826 & 14.7 & 122 & 61 & 50 \\
$\mathrm{D}$ & 1.5 & 32 & 19 & 13 & 18 & 1970 & 11.6 & 412 & 206 & 77 \\
$\mathrm{E}$ & 1.5 & 34 & 20 & 14 & 16 & 2015 & 10.1 & 375 & 187.5 & 87 \\
$\mathrm{~F}$ & 1.5 & 38 & 21 & 17 & 20 & 1796 & 16.8 & 216 & 108 & 48 \\
\hline
\end{tabular}

an unsaturated soil [18-21]. Artificial neural networks and multivariate regression have also been applied to estimate the shear strength of soils [22-24].

According to Murthy [25], soil survey ranges from visual inspection of trail pits to an extensive borehole investigation with deep and numerous boreholes and extensive sampling and testing of the soil, usually by investigation specialist. Soil investigation is a necessary process which should be carried out prior to commencement of actual construction work. Tests to determine the shear strength or density of soils in situ are a valuable means of investigation since these characteristics can be obtained directly without the disturbing effect of boring and sampling $[15,17]$.

\section{Research Methodology}

The method used in the sample collection is the trial pit method. Undisturbed block samples were collected from six (6) different trial pits each in different sites in FUTA. These sites and their locations are listed below:

(i) proposed site for school of mines and earth science which is sample A;

(ii) new library complex which is sample B;

(iii) centre for continuing education (CCE) which is sample C;

(iv) engineering workshop complex which is sample $\mathrm{D}$;

(v) malu road, that is, behind Abiola Hall, sample E;

(vi) proposed site for hostel accommodation which is sample F.

2.1. Test or Trial Pits. This is the method of site exploration that was used in this research work. A test pit is simply a hole dug in the ground that is large enough for a ladder to be inserted, thus permitting a close examination of the sides. With this method, relatively undisturbed samples of soils were collected.

The depth of each trial pit was $1.5 \mathrm{~m}(5 \mathrm{ft})$ and about $4 \mathrm{ft} \times$ $4 \mathrm{ft}$ wide that is, $1.2 \mathrm{~m} \times 1.2 \mathrm{~m} \times 1.5 \mathrm{~m}$ pit. The types of samples collected for the laboratory analysis are as follows.

(i) Disturbed samples.

(ii) Undisturbed samples.
The pit was sunk by hand excavation with the aid of spade and digger.

2.2. Undisturbed Sample. Undisturbed samples are required for shear strength tests on the soil. Undisturbed block samples were cut by hand from the bottom of the pits. During cutting the samples are protected from water, wind, and sun to avoid any change in water content. The samples are covered with black polythene bag immediately; they are brought to the surface, and the samples are carefully labelled, respectively. The block undisturbed samples collected had a size of about $225 \mathrm{~mm} \times 225 \mathrm{~mm} \times 225 \mathrm{~mm}$.

2.3. Disturbed Sample. Disturbed samples are used mainly for soil classification and compaction tests. These were also collected from the trial pits.

2.4. Laboratory Work. After collection of the samples, the following basic and detailed tests were conducted:

(A) classification tests:

(i) moisture content;

(ii) liquid limit;

(iii) plastic limit;

(iv) particle size analysis;

(v) specific gravity;

(B) soil improvement/property tests;

(i) compaction test;

(ii) in situ density;

(C) strength tests:

(i) unconfined compression test;

(ii) california bearing ratio (CBR) test.

Tests which were classified as basic tests include

(1) moisture content test;

(2) liquid Limit test;

(3) plastic limit test;

(4) particle size analysis test; 
TABLE 2: Summary of soil identification and classification for the lateritic soils.

\begin{tabular}{|c|c|}
\hline Sample A & Fine grained reddish clayey silt, A-4 (5) \\
\hline Sample B & $\begin{array}{l}\text { Mottled (brown and yellow), fine grained } \\
\text { clayey silt, A-4 (6) }\end{array}$ \\
\hline Sample C & Reddish brown silty clay, A-7-6 (10) \\
\hline Sample D & $\begin{array}{l}\text { Mottled (yellowish brown), coarse grained } \\
\text { sandy clay with gravel, A-2-6 (0) }\end{array}$ \\
\hline Sample E & $\begin{array}{l}\text { Mottled (yellowish brown), medium to } \\
\text { coarse grained clayey sand with } \\
\text { gravel, A-2-6 (3) }\end{array}$ \\
\hline Sample F & $\begin{array}{l}\text { Mottled (yellowish brown and reddish), } \\
\text { sandy clay, A-6 (4) }\end{array}$ \\
\hline
\end{tabular}

TABLE 3: Summary of the CBR results with other soil parameters.

\begin{tabular}{lcccccc}
\hline $\begin{array}{l}\text { CBR } \\
(\%)\end{array}$ & $\begin{array}{c}\text { OMC } \\
(\%)\end{array}$ & $\begin{array}{c}\text { NMC } \\
(\%)\end{array}$ & GI & $\begin{array}{c}\text { BulD } \\
\left(\mathrm{kg} / \mathrm{m}^{3}\right)\end{array}$ & $\begin{array}{c}\text { MDD } \\
\left(\mathrm{kg} / \mathrm{m}^{3}\right)\end{array}$ & $\begin{array}{c}\mathrm{InD} \\
\left(\mathrm{kg} / \mathrm{m}^{3}\right)\end{array}$ \\
\hline 35 & 20.6 & 25 & 5 & 2048.5 & 1652 & 1638.3 \\
45 & 17.8 & 24 & 6 & 2124 & 1740 & 1712.9 \\
50 & 14.7 & 21 & 10 & 2201.1 & 1826 & 1819.1 \\
77 & 11.6 & 18 & 0 & 2314.4 & 1970 & 1961.4 \\
87 & 10.1 & 16 & 3 & 2335.4 & 2015 & 2013.1 \\
48 & 16.8 & 20 & 4 & 2265.1 & 1796 & 1887.6 \\
\hline
\end{tabular}

(5) specific gravity test;

(6) compaction test;

(7) in situ density test.

While the detailed tests include

(1) unconfined compression test;

(2) california bearing test.

The unconfined compression test is the simplest form of shear strength test. It cannot be made for cohesionless soil or on clay and silt which are too soft to stand in the machine without collapsing before the load is applied [26]. In the case of fissured or brittle soils, the results are lower than the true in situ strength of these soils. The strength of a subgrade, subbase and base course materials for road construction is expressed in terms of their California bearing ratio (CBR) value. The CBR value is the resistance to a penetration of $2.5 \mathrm{~mm}$ of a standard cylindrical plunger of $50 \mathrm{~mm}$ diameter, expressed as a percentage of the known resistance of the plunger to $2.5 \mathrm{~mm}$ in penetration in crushed aggregate (taken as $13.2 \mathrm{kN}$ ).

All tests were performed in accordance to BS1377 [27] and BS5930 [28]. Statistical analysis was performed using the Statistical Product and Service Solutions (SPSS) software.

\section{Results}

The result of the particle size distribution analysis for the samples tested for different trial pits is shown in Figure 1.

This gives the percentage occurrence of different grain sizes within the soil mass, which in turn is used to describe
TABLE 4: Summary of the undrained shear strength $\left(S_{u}\right)$ and other soil parameters.

\begin{tabular}{lcccccc}
\hline $\begin{array}{l}S_{u} \\
(\mathrm{kPa})\end{array}$ & $\begin{array}{c}\text { OMC } \\
(\%)\end{array}$ & $\begin{array}{c}\mathrm{NMC} \\
(\%)\end{array}$ & GI & $\begin{array}{c}\mathrm{BulD} \\
\left(\mathrm{kg} / \mathrm{m}^{3}\right)\end{array}$ & $\begin{array}{c}\mathrm{MDD} \\
\left(\mathrm{kg} / \mathrm{m}^{3}\right)\end{array}$ & $\begin{array}{c}\mathrm{InD} \\
\left(\mathrm{kg} / \mathrm{m}^{3}\right)\end{array}$ \\
\hline 35.5 & 20.6 & 25 & 5 & 2048.5 & 1652 & 1638.3 \\
53 & 17.8 & 24 & 6 & 2124 & 1740 & 1712.9 \\
61 & 14.7 & 21 & 10 & 2201.1 & 1826 & 1819.1 \\
206 & 11.6 & 18 & 0 & 2314.4 & 1970 & 1961.4 \\
187.6 & 10.1 & 16 & 3 & 2335.4 & 2015 & 2013.1 \\
108 & 16.8 & 20 & 4 & 2265.1 & 1796 & 1887.6 \\
\hline
\end{tabular}

the soil. The result of the sieve analyses shows that the range of sand fraction for the samples that lies between $34 \%$ and $93 \%$, while the range of clay and silt fraction is from 0 to $47 \%$. Atterberg limit tests performed include the liquid limit $\left(W_{L}\right)$ and the plastic limit $\left(W_{P}\right)$. The plasticity index $(\mathrm{PI})$ is the difference between the liquid limit and the plastic limit. It is the behaviour of the soil in relation to the mass of water in the soil, that is, the consistency limits. The test result is as shown in the summary in Table 1 . The natural moisture content ranges from $16 \%$ to $25 \%$.

General soil identification and classification from the various tests are presented in Table 2 . To evaluate the quality of a soil as a highway subgrade material, a number called the group index (G1) must be incorporated with the AASHTO groups and subgroups of the soil. This index is written in parentheses after the group or subgroup designation. The group index is determined based on the Atterberg limits and the percentage of soil particles finer than $0.075 \mathrm{~mm}$. Group index values near 0 indicate good soils, while values of 20 or more indicate very poor soils [29]. These lateritic soils fall within the A-2, A- 6 , and A-7 groups in the AASHTO classification system with group index between 0 and 10 .

The moisture-density relationship was determined by the use of standard proctor method. A summary of the result of compaction tests on the six different samples is in Table 1 . The maximum dry density varies from 1652 to $2015 \mathrm{~kg} / \mathrm{m}^{3}$, and the optimum moisture content varies from $10.1 \%$ to $20.6 \%$. The maximum dry density (MDD) increases with the decrease in optimum moisture content. The higher the MDD, the more stable the soil. The result of the unconfined compressive strength test on the soil samples obtained from the field is summarized in Table 1. For cohesive soil, the unconfined compressive strength (UCS) is related to the undrained shear strength $\left(S_{u}\right)$; such a relationship is suggested in BS 5930 [27]. From the results, samples D and E soils are regarded as hard, while the remaining samples range from stiff to very stiff. The laboratory California bearing ratio (CBR) (BS1377: [27] Part $4: 7)$ test measures the shearing resistance of a soil under controlled moisture and density conditions. The CBR number is used to rate the performance of soils primarily for the use as base and subbase courses beneath the pavement of roads and airfields. The result of the CBR tests that were conducted in the laboratory is summarized in Table 1. Most of the soils could not meet the $80 \%$ CBR value, ideal for road base construction, but were good for road subbase construction. 
TABLE 5: Total variance explained.

\begin{tabular}{lccccc}
\hline Component & Total & $\begin{array}{c}\text { Initial eigenvalues } \\
\text { \% of variance }\end{array}$ & Cumulative \% & Total & Extraction sums of squared loadings \\
\% of variance & Cumulative \% \\
\hline 1 & 5.127 & 85.457 & 85.457 & 5.127 & 85.457 \\
2 & 0.724 & 12.074 & 97.531 & & \\
3 & 0.130 & 2.172 & 99.702 & \\
4 & 0.018 & 0.296 & 99.998 & \\
5 & 0.000 & 0.002 & 100.000 & \\
6 & $-6.3 E-016$ & $-1.04 E-014$ & 100.000 & \\
\hline
\end{tabular}

Extraction method: principal component analysis.

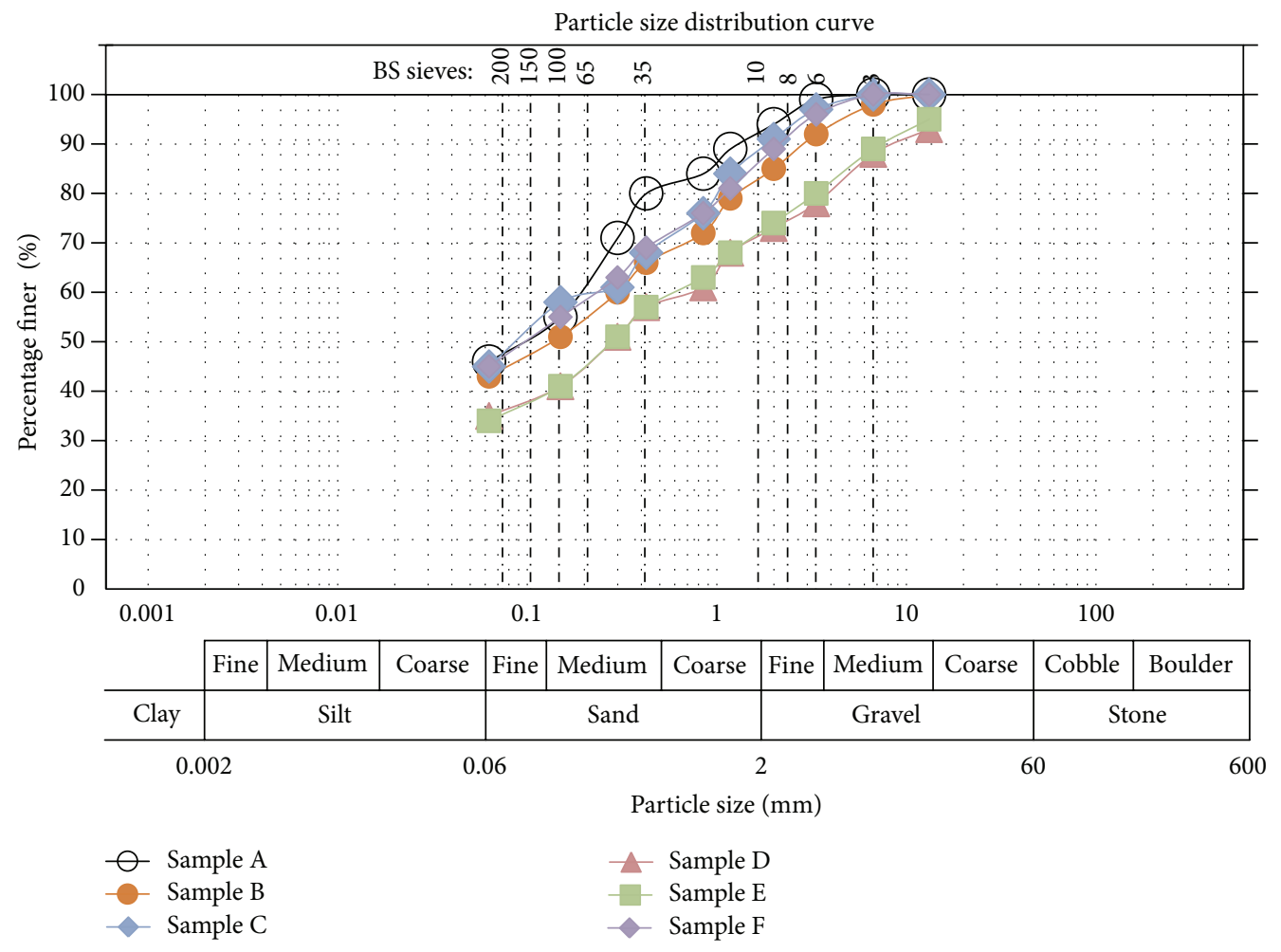

FIGURE 1: Result of particle size distribution analysis.

TABle 6: Component matrix ${ }^{\mathrm{a}}$.

\begin{tabular}{lc}
\hline & Component 1 \\
\hline $\operatorname{InD}\left(\mathrm{Kg} / \mathrm{m}^{3}\right)$ & 0.989 \\
$\mathrm{NMC}(\%)$ & -0.988 \\
$\operatorname{MDD}\left(\mathrm{Kg} / \mathrm{m}^{3}\right)$ & 0.982 \\
$\operatorname{BulD}\left(\mathrm{Kg} / \mathrm{m}^{3}\right)$ & 0.978 \\
OMC $(\%)$ & -0.960 \\
GI & -0.576 \\
\hline
\end{tabular}

Extraction method: principal component analysis.

${ }^{\mathrm{a}} 1$ components extracted.

\section{Discussion of the Test Results}

A summary of the various soil parameters of the different soil samples for the comparative study is shown in Tables 3 and 4, respectively. Principal components analysis based on the correlation matrix of the variables was used to find optimal ways of combining the six correlated independent variables, namely, in situ density (InD), bulk density (BulD), maximum dry density (MDD), optimum moisture content (OMC), natural moisture content (NMC), and group index (GI) into a small number of subsets. Only one principal component out of six had eigenvalue greater than 1 . Component 1 explained $85.457 \%$ of total variance. All the other components had eigenvalues less than 1 which account for less variance, and so they are of little use (Table 5). Table 6 displays each variable's loading on the extracted component. Since the correlation matrix was not positively definite, the KMO (Kaiser-Meyer-Olkin) and Bartlett's test conditions were not satisfied for the principal component analysis to be commended. Stepwise multiple regression was then used to establish predictive equations for the dependent variables of California bearing ratio (CBR) and undrained shear strength $\left(S_{u}\right)$. 
TABLE 7: Correlations (CBR).

\begin{tabular}{|c|c|c|c|c|c|c|c|}
\hline & CBR (\%) & OMC (\%) & NMC (\%) & GI & $\operatorname{BulD}\left(\mathrm{kg} / \mathrm{m}^{3}\right)$ & $\operatorname{MDD}\left(\mathrm{kg} / \mathrm{m}^{3}\right)$ & $\operatorname{InD}\left(\mathrm{kg} / \mathrm{m}^{3}\right)$ \\
\hline \multicolumn{8}{|l|}{ Pearson correlation } \\
\hline CBR (\%) & 1.000 & -0.965 & -0.930 & -0.587 & 0.878 & 0.980 & 0.908 \\
\hline OMC (\%) & -0.965 & 1.000 & 0.946 & 0.409 & -0.913 & -0.994 & -0.932 \\
\hline NMC (\%) & -0.930 & 0.946 & 1.000 & 0.494 & -0.977 & -0.965 & -0.992 \\
\hline GI & -0.587 & 0.409 & 0.494 & 1.000 & -0.508 & -0.498 & -0.514 \\
\hline $\operatorname{BulD}\left(\mathrm{kg} / \mathrm{m}^{3}\right)$ & 0.878 & -0.913 & -0.977 & -0.508 & 1.000 & 0.936 & 0.996 \\
\hline $\operatorname{MDD}\left(\mathrm{kg} / \mathrm{m}^{3}\right)$ & 0.980 & -0.994 & -0.965 & -0.498 & 0.936 & 1.000 & 0.955 \\
\hline $\operatorname{InD}\left(\mathrm{kg} / \mathrm{m}^{3}\right)$ & 0.908 & -0.932 & -0.992 & -0.514 & 0.996 & 0.955 & 1.000 \\
\hline \multicolumn{8}{|l|}{ Sig. (1 tailed) } \\
\hline CBR (\%) & - & 0.001 & 0.004 & 0.110 & 0.011 & 0.000 & 0.006 \\
\hline OMC (\%) & 0.001 & - & 0.002 & 0.210 & 0.006 & 0.000 & 0.003 \\
\hline NMC (\%) & 0.004 & 0.002 & - & 0.159 & 0.000 & 0.001 & 0.000 \\
\hline GI & 0.110 & 0.210 & 0.159 & - & 0.152 & 0.157 & 0.148 \\
\hline $\operatorname{BulD}\left(\mathrm{kg} / \mathrm{m}^{3}\right)$ & 0.011 & 0.006 & 0.000 & 0.152 & - & 0.003 & 0.000 \\
\hline $\operatorname{MDD}\left(\mathrm{kg} / \mathrm{m}^{3}\right)$ & 0.000 & 0.000 & 0.001 & 0.157 & 0.003 & - & 0.002 \\
\hline $\operatorname{InD}\left(\mathrm{kg} / \mathrm{m}^{3}\right)$ & 0.006 & 0.003 & 0.000 & 0.148 & 0.000 & 0.002 & - \\
\hline \multicolumn{8}{|l|}{$N$} \\
\hline CBR (\%) & 6 & 6 & 6 & 6 & 6 & 6 & 6 \\
\hline OMC (\%) & 6 & 6 & 6 & 6 & 6 & 6 & 6 \\
\hline NMC (\%) & 6 & 6 & 6 & 6 & 6 & 6 & 6 \\
\hline GI & 6 & 6 & 6 & 6 & 6 & 6 & 6 \\
\hline $\operatorname{BulD}\left(\mathrm{kg} / \mathrm{m}^{3}\right)$ & 6 & 6 & 6 & 6 & 6 & 6 & 6 \\
\hline $\operatorname{MDD}\left(\mathrm{kg} / \mathrm{m}^{3}\right)$ & 6 & 6 & 6 & 6 & 6 & 6 & 6 \\
\hline $\operatorname{InD}\left(\mathrm{kg} / \mathrm{m}^{3}\right)$ & 6 & 6 & 6 & 6 & 6 & 6 & 6 \\
\hline
\end{tabular}

TABLE 8: Model summary ${ }^{\mathrm{b}}$.

\begin{tabular}{lccccc}
\hline Model & $R$ & $\begin{array}{c}R \\
\text { square }\end{array}$ & $\begin{array}{c}\text { Adjusted } R \\
\text { square }\end{array}$ & $\begin{array}{c}\text { Std. error of the } \\
\text { estimate }\end{array}$ & $\begin{array}{c}\text { Durbin- } \\
\text { Watson }\end{array}$ \\
\hline $1 \quad 0.980^{\mathrm{a}}$ & 0.960 & 0.950 & 4.535 & 2.035 \\
\hline${ }^{\mathrm{a}}$ Predictors: (constant), $\mathrm{MDD}\left(\mathrm{kg} / \mathrm{m}^{3}\right)$. \\
\\
${ }^{\mathrm{b}}$ Dependent variable: $\mathrm{CBR}(\%)$.
\end{tabular}

TABLE 9: ANOVA ${ }^{\mathrm{b}}$.

\begin{tabular}{lcccccc}
\hline \multicolumn{1}{c}{ Model } & Sum of squares & df & Mean square & $F$ & Sig. \\
\hline & Regression & 1975.726 & 1 & 1975.726 & 96.056 & $0.001^{\mathrm{a}}$ \\
1 & Residual & 82.274 & 4 & 20.569 & & \\
& Total & 2058.000 & 5 & & & \\
\hline
\end{tabular}

"Predictors: (constant), MDD $\left(\mathrm{kg} / \mathrm{m}^{3}\right)$.

${ }^{\mathrm{b}}$ Dependent variable: CBR (\%).

4.1. Relationship between California Bearing Ration (CBR) and Other Soil Parameters. For the stepwise multiple regression, the CBR correlation table (Table 7) shows three things. First, it shows the value of the pearson correlation coefficient between every pair of variable. The MDD $\left(\mathrm{kg} / \mathrm{m}^{3}\right)$ had a large positive correlation with $\mathrm{CBR}(\%) R=0.980$. Second, the one tailed significance of each correlation is displayed. The CBR-MDD correlation is significant with $P<0.001$. The number of cases contributing to each correlation $N=6$ is also shown on this Table. The correlation is extremely useful for getting a rough idea of the relationships between the predictors (independent variables) and the outcome (dependent variable) and for a preliminary look for multicollinearity. If there is no multicollinearity in the data then there shall be no substantial correlation. The next section of the output (Table 8) describes the overall model and indicates whether the model is successful in predicting the CBR. Since stepwise (hierarchical) regression is used, each set of the summary statistics was repeated for each stage in the hierarchy. Table 8 has only one model (model 1). Model 1 refers to the first and only stage in the hierarchy when only the $\operatorname{MDD}\left(\mathrm{kg} / \mathrm{m}^{3}\right)$ is used as predictor. In the column labelled $R$ is the value of the correlation coefficient between the predictor and the outcome when only MDD is used as a predictor. This is the simple correlation between the predictor and the outcome variable $(R=0.980)$. The next column gives the value of $R^{2}$, which is a measure of how much of the variability in the outcome is accounted for by the predictor. For the model its value is 0.960, which means that MDD alone accounts for $96 \%$ of the variation in CBR. The next part of the analysis contains the analysis of variance (ANOVA) (Table 9), which test whether the model is significantly better at predicting the outcome than using the mean as a "best guess". Specifically, the $F$ ratio represents the ratio of the improvement in prediction that results from fitting the model, relative to the inaccuracy that still exists in the model. For the model $F$ ratio $(F)$ is 96.056 , 
TABle 10: Coefficients ${ }^{\mathrm{a}}$.

\begin{tabular}{|c|c|c|c|c|c|c|}
\hline \multirow{2}{*}{\multicolumn{2}{|c|}{ Model }} & \multicolumn{2}{|c|}{ Unstandardized coefficients } & \multirow{2}{*}{$\begin{array}{c}\text { Standardized coefficients } \\
\text { Beta }\end{array}$} & \multirow{2}{*}{$t$} & \multirow{2}{*}{ Sig. } \\
\hline & & $B$ & Std. Error & & & \\
\hline \multirow{2}{*}{1} & (Constant) & -207.754 & 27.077 & & -7.673 & 0.002 \\
\hline & $\operatorname{MDD}\left(\mathrm{Kg} / \mathrm{m}^{3}\right)$ & 0.144 & 0.015 & 0.980 & 9.801 & 0.001 \\
\hline
\end{tabular}

${ }^{a}$ Dependent variable: CBR (\%).

TABle 11: Correlations $\left(S_{u}\right)$.

\begin{tabular}{|c|c|c|c|c|c|c|c|}
\hline & $S_{u}(\mathrm{kPa})$ & $\mathrm{OMC}(\%)$ & NMC (\%) & GI & $\operatorname{BulD}\left(\mathrm{kg} / \mathrm{m}^{3}\right)$ & $\operatorname{MDD}\left(\mathrm{kg} / \mathrm{m}^{3}\right)$ & $\operatorname{InD}\left(\mathrm{kg} / \mathrm{m}^{3}\right)$ \\
\hline \multicolumn{8}{|l|}{ Pearson correlation } \\
\hline$S_{u}(\mathrm{kPa})$ & 1.000 & -0.886 & -0.915 & -0.776 & 0.908 & 0.929 & 0.920 \\
\hline $\mathrm{OMC}(\%)$ & -0.886 & 1.000 & 0.946 & 0.409 & -0.913 & -0.994 & -0.932 \\
\hline NMC (\%) & -0.915 & 0.946 & 1.000 & 0.494 & -0.977 & -0.965 & -0.992 \\
\hline GI & -0.776 & 0.409 & 0.494 & 1.000 & -0.508 & -0.498 & -0.514 \\
\hline $\operatorname{BulD}\left(\mathrm{kg} / \mathrm{m}^{3}\right)$ & 0.908 & -0.913 & -0.977 & -0.508 & 1.000 & 0.936 & 0.996 \\
\hline $\operatorname{MDD}\left(\mathrm{kg} / \mathrm{m}^{3}\right)$ & 0.929 & -0.994 & -0.965 & -0.498 & 0.936 & 1.000 & 0.955 \\
\hline $\operatorname{InD}\left(\mathrm{kg} / \mathrm{m}^{3}\right)$ & 0.920 & -0.932 & -0.992 & -0.514 & 0.996 & 0.955 & 1.000 \\
\hline \multicolumn{8}{|l|}{ Sig. (1-tailed) } \\
\hline$S_{u}(\mathrm{kPa})$ & - & 0.009 & 0.005 & 0.035 & 0.006 & 0.004 & 0.005 \\
\hline OMC (\%) & 0.009 & - & 0.002 & 0.210 & 0.006 & 0.000 & 0.003 \\
\hline NMC (\%) & 0.005 & 0.002 & - & 0.159 & 0.000 & 0.001 & 0.000 \\
\hline GI & 0.035 & 0.210 & 0.159 & - & 0.152 & 0.157 & 0.148 \\
\hline $\operatorname{BulD}\left(\mathrm{kg} / \mathrm{m}^{3}\right)$ & 0.006 & 0.006 & 0.000 & 0.152 & - & 0.003 & 0.000 \\
\hline $\operatorname{MDD}\left(\mathrm{kg} / \mathrm{m}^{3}\right)$ & 0.004 & 0.000 & 0.001 & 0.157 & 0.003 & - & 0.002 \\
\hline $\operatorname{InD}\left(\mathrm{kg} / \mathrm{m}^{3}\right)$ & 0.005 & 0.003 & 0.000 & 0.148 & 0.000 & 0.002 & - \\
\hline \multicolumn{8}{|l|}{$N$} \\
\hline$S_{u}(\mathrm{kPa})$ & 6 & 6 & 6 & 6 & 6 & 6 & 6 \\
\hline OMC (\%) & 6 & 6 & 6 & 6 & 6 & 6 & 6 \\
\hline NMC (\%) & 6 & 6 & 6 & 6 & 6 & 6 & 6 \\
\hline GI & 6 & 6 & 6 & 6 & 6 & 6 & 6 \\
\hline $\operatorname{BulD}\left(\mathrm{kg} / \mathrm{m}^{3}\right)$ & 6 & 6 & 6 & 6 & 6 & 6 & 6 \\
\hline $\operatorname{MDD}\left(\mathrm{kg} / \mathrm{m}^{3}\right)$ & 6 & 6 & 6 & 6 & 6 & 6 & 6 \\
\hline $\operatorname{InD}\left(\mathrm{kg} / \mathrm{m}^{3}\right)$ & 6 & 6 & 6 & 6 & 6 & 6 & 6 \\
\hline
\end{tabular}

TABle 12: Model Summary ${ }^{\mathrm{c}}$.

\begin{tabular}{lccccc}
\hline Model & $R$ & $\begin{array}{c}R \\
\text { square }\end{array}$ & $\begin{array}{c}\text { Adjusted } R \\
\text { square }\end{array}$ & $\begin{array}{c}\text { Std. error of } \\
\text { the estimate }\end{array}$ & $\begin{array}{c}\text { Durbin- } \\
\text { Watson }\end{array}$ \\
\hline 1 & $0.929^{\mathrm{a}}$ & 0.863 & 0.829 & 30.0900 & \\
2 & $0.997^{\mathrm{b}}$ & 0.994 & 0.989 & 7.5638 & 2.451 \\
\hline
\end{tabular}

aredictors: (constant), MDD $\left(\mathrm{kg} / \mathrm{m}^{3}\right)$.

${ }^{b}$ Predictors: (constant), MDD ( $\left.\mathrm{kg} / \mathrm{m}^{3}\right)$, GI.

${ }^{\mathrm{c}}$ Dependent variable: $S_{u}(\mathrm{kPa})$.

which is very unlikely to have happened by chance $(P<$ 0.005). We can interpret this result meaning that the model is significantly improved in ability to predict the outcome variable. Table of coefficients (Table 10) is concerned with the parameters of the model.

The model include only the MDD $\left(\mathrm{kg} / \mathrm{m}^{3}\right)$ as the predictor variable. The model is of the form $\mathrm{CBR}=b_{0}+b_{1} \mathrm{MDD}$,
TABle 13: ANOVA $^{\mathrm{c}}$.

\begin{tabular}{|c|c|c|c|c|c|c|}
\hline \multicolumn{2}{|c|}{ Model } & Sum of squares & \multirow{2}{*}{$\frac{\mathrm{df}}{1}$} & Mean square & \multirow{2}{*}{$\begin{array}{c}F \\
25.190\end{array}$} & \multirow{2}{*}{$\frac{\text { Sig. }}{0.007^{\mathrm{a}}}$} \\
\hline \multirow{3}{*}{1} & Regression & 22807.174 & & 22807.174 & & \\
\hline & Residual & 3621.635 & 4 & 905.409 & & \\
\hline & Total & 26428.808 & 5 & & & \\
\hline \multirow{3}{*}{2} & Regression & 26257.175 & 2 & 13128.588 & 229.476 & $0.001^{\mathrm{b}}$ \\
\hline & Residual & 171.633 & 3 & 57.211 & & \\
\hline & Total & 26428.808 & 5 & & & \\
\hline
\end{tabular}

where $b_{0}$ and $b_{1}$ are the model parameters, and $b_{0}$ is the intercept, from the table (Table 10); this value is -207.754 . $b_{1}$ represents the gradient of the regression line; from the table this value is 0.144 . Although this value is the slope of the regression line, it is more useful to think of this value as 
TABle 14: Coefficients ${ }^{\mathrm{a}}$.

\begin{tabular}{|c|c|c|c|c|c|c|}
\hline \multirow{2}{*}{ Model } & & \multicolumn{2}{|c|}{ Unstandardized coefficients } & \multirow{2}{*}{$\begin{array}{c}\text { Standardized coefficients } \\
\text { Beta }\end{array}$} & \multirow{2}{*}{$t$} & \multirow{2}{*}{ Sig. } \\
\hline & & $B$ & Std. error & & & \\
\hline \multirow{2}{*}{1} & (Constant) & -791.012 & 179.647 & & -4.403 & 0.012 \\
\hline & $\operatorname{MDD}\left(\mathrm{Kg} / \mathrm{m}^{3}\right)$ & 0.491 & 0.098 & 0.929 & 5.019 & 0.007 \\
\hline \multirow{3}{*}{2} & (Constant) & -547.713 & 54.963 & & -9.965 & 0.002 \\
\hline & $\operatorname{MDD}\left(\mathrm{Kg} / \mathrm{m}^{3}\right)$ & 0.381 & 0.028 & 0.722 & 13.451 & 0.001 \\
\hline & GI & -9.104 & 1.172 & -0.417 & -7.766 & 0.004 \\
\hline
\end{tabular}

a Dependent variable: $S_{u}(\mathrm{kPa})$.

representing the change in the outcome associated with a unit change in the predictor. The established model for predicting the California bearing ratio (CBR) of the lateritic soils is

$$
\begin{aligned}
& \text { CBR }=-207.754+0.144 \mathrm{MDD}, \\
& \left(F_{1,4}=96.056, P<0.005, \text { Adjusted } R^{2}=0.950,\right. \\
& \text { Std. Error }=4.535) .
\end{aligned}
$$

For the included predictor variable beta $=0.980, P<0.005$ for MDD, where other variables are excluded from the model.

4.2. Relationship between Undrained Shear Strength $\left(S_{u}\right)$ and Other Soil Parameters. For the stepwise multiple regression, the undrained shear strength $\left(S_{u}\right)$ correlation table is Table 11. The overall model, Table 12, has two models (models 1 and 2 ). The first model uses MDD as the only dependent variable with $R^{2}$ of 0.863 , meaning that MDD alone accounts for $86.3 \%$ of the variation in the dependent variable, and the model is given as

$$
\begin{aligned}
& S_{u}=-791.012+0.491 \mathrm{MDD}, \\
& \left(F_{1,4}=25.190, P<0.01 \text {, Adjusted } R^{2}=0.829,\right.
\end{aligned}
$$

Std. Error $=30.09)$,

where other variables are excluded from this model, the model considers the MDD as the best variable that explains the dependent variable because it accounts for almost all the variations in the dependent variable; it does not account for $100-86.0=13.7 \%$ of the variation. The second model includes another variable (Group index (GI)) into the model and the new model is given as

$$
\begin{aligned}
& S_{u}=-547.713+0.381 \mathrm{MDD}-9.104 \mathrm{GI}, \\
& \left(F_{2,3}=229.476, P<0.005, \text { Adjusted } R^{2}=0.989,\right.
\end{aligned}
$$

$$
\text { Std. Error }=7.5638) \text {. }
$$

The $R^{2}$ for (3) is $99.4 \%$, meaning that the second model account for $99.4 \%$ of the variation in the dependent variable, since MDD alone has accounted for $86.3 \%$, therefore GI accounts for $99.4-86.3=13.1 \%$. Since the percentage explained by the second model is greater than the first model, the second model should be considered as the best model that explains the dependent variable, and this model makes use of MDD and GI as the explanatory variables, while other variables are excluded. The analysis of variance (ANOVA) and model coefficients are summarized in Tables 13 and 14. For the included predictor variables beta $=0.722, P<0.005$ and beta $=-0.417, P<0.005$ for MDD and GI, respectively.

\section{Conclusions}

An increase in in situ density (InD), bulk density (BulD), and maximum dry density (MDD) gave a corresponding increase in the dependent variables of California bearing ratio $(\mathrm{CBR})$ and undrained shear strength $\left(S_{u}\right)$. While a decrease in optimum moisture content (OMC), natural moisture content (NMC), and group index (GI) of the soils led to an increase in the dependent variables for the soils. The regression models, (1) and (3), are proposed for the estimation of the CBR and the undrained shear strength $\left(S_{u}\right)$ of tropical lateritic soils. The high coefficients of determination for the various recommended relations allude to the reliability of the empirical relations and to a great extent allay the fear of erroneous shear strength prediction, using them.

The proposed relationships can serve as an indirect method of establishing soil shear strength and compressibility. The result of these tests will be useful to both individuals and government agencies, involved in building construction, who may be worried about the huge cost of those detailed soil strength tests and the time consumed in conducting them.

These derived relations and equations can be used for the prediction of the shear strength of similar tropical lateritic soils, especially in the estimation of soil shear strength for the preliminary/first phase engineering design of engineering infrastructure.

\section{Acknowledgments}

The author is am grateful to project student J. N. Ejechi, for his involvement in data collection. Dr Philip Oguntunde and Mr Nurudeen Adegoke are acknowledged for their assistance in the statistical analysis.

\section{References}

[1] H. Singh and B. B. K. Huat, "Origin, formation and occurrence of tropical residual soils," in Tropical Residual Soils Engineering, 
B. B. K. Huat, G. See-Sew, and F. H. Ali, Eds., Taylor \& Francis, London, UK, 2004.

[2] G. Baldovin, "The shear strength of lateritic soils," in Proceedings of the Specialty Session on Engineering Properties of Lateritic Soiles of the 7th International Conference on Soil Mechanics and Foundation Engineering, vol. 1, pp. 129-142, Mexico City, Mexico.

[3] S. Malomo, "The compressibility characteristics of a compacted laterite soil," Bulletin of the International Association of Engineering Geology, vol. 24, no. 1, pp. 151-154, 1981.

[4] S. Malomo, "Stress-strain behaviour of some compacted laterite soils from north-east Brazil," Bulletin of the International Association of Engineering Geology, vol. 28, no. 1, pp. 49-54, 1983.

[5] S. Malomo, "Microstructural investigation on latérite soils," Bulletin of the International Association of Engineering Geology, vol. 39, no. 1, pp. 105-109, 1989.

[6] O. Ogunsanwo, "Variability in the shear strength characteristics af an amphibolite derived laterite soil," Bulletin of the International Association of Engineering Geology, no. 32, pp. 111-115, 1985.

[7] M. D. Gidigasu, Laterite Soil Engineering-Pedogenesis and Engineering Principles, Elsevier, Amsterdam, The Netherlands, 1976.

[8] S. Malomo, "Stress-strain behaviour of some compacted laterite soils," Revista Brasileira da Geologia, vol. 2, 1980.

[9] R. M. Madu, "An investigation into the geotechnical and engineering properties of some laterites of Eastern Nigeria," Engineering Geology, vol. 11, no. 2, pp. 101-125, 1977.

[10] S. A. Ola, "Geotechnical properties and behaviour of some stabilized Nigerian lateritic soils," Quarterly Journal of Engineering Geology and Hydrogeology, vol. 11, pp. 145-160, 1978.

[11] S. A. Ola, "Permeability of three compacted tropical soils," Quarterly Journal of Engineering Geology, vol. 13, no. 2, pp. 8795, 1980.

[12] S. A. Ola, "Geotechnical properties and behaviour of some Nigerian lateritic soils," in Tropical Soils of Nigeria in Engineering Practice, S. A. Ola, Ed., pp. 61-84, A. A. Balkema, Rotterdam, The Netherlands, 1983.

[13] O. Ogunsanwo, "Basic index properties, mineralogy and microstructure of an amphibolite derived laterite soil," Bulletin of the International Association of Engineering Geology, vol. 33, no. 1, pp. 19-25, 1986.

[14] O. Ogunsanwo, "Some geotechnical properties of two laterite soils compacted at different energies," Engineering Geology, vol. 26, no. 3, pp. 261-269, 1989.

[15] S. Malomo, "Penetration resistance and basic engineering properties of laterite profile soils," in Proceedings of the 5th International Association of Engineering Geology Congress (IAEG '86), pp. 821-828, Buenos Aires, Argentina, 1986.

[16] E. A. Mesida, "The relationship between the geology and the lateritic engineering soils in the northern environs of Akure, Nigeria," Bulletin of the International Association of Engineering Geology, vol. 35, no. 1, pp. 65-69, 1987.

[17] M. Fall, J. P. Tisot, and I. K. Cisse, "Specifications for road design using statistical data, an example of laterite or gravel lateritic soils from Senegal," Bulletin of the International Association of Engineering Geology, vol. 50, pp. 17-35, 1994.

[18] L. Miao, S. Liu, and Y. Lai, "Research of soil-water characteristics and shear strength features of Nanyang expansive soil," Engineering Geology, vol. 65, no. 4, pp. 261-267, 2002.

[19] M. A. Tekinsoy, C. Kayadelen, M. S. Keskin, and M. Söylemez, "An equation for predicting shear strength envelope with respect to matric suction," Computers and Geotechnics, vol. 31, no. 7, pp. 589-593, 2004.

[20] S. Nam, M. Gutierrez, P. Diplas, and J. Petrie, "Determination of the shear strength of unsaturated soils using the multistage direct shear test," Engineering Geology, vol. 122, no. 3-4, pp. 272280, 2011.

[21] A. Zhou, D. Sheng, S. W. Sloan, and A. Antonio Gens, "Interpretation of unsaturated soil behaviour in the stress-Saturation space, I: volume change and water retention behavior," Computers and Geotechnics, vol. 43, pp. 178-187, 2012.

[22] B. S. Narendra, P. V. Sivapullaiah, S. Suresh, and S. N. Omkar, "Prediction of unconfined compressive strength of soft grounds using computational intelligence techniques: a comparative study," Computers and Geotechnics, vol. 33, no. 3, pp. 196-208, 2006.

[23] M. Ajdari, G. Habibagahi, and A. Ghahramani, "Predicting effective stress parameter of unsaturated soils using neural networks," Computers and Geotechnics, vol. 40, pp. 89-96, 2012.

[24] G. R. Khanlari, M. Heidari, A. A. Momeni, and Y. Abdilor, "Prediction of shear strength parameters of soils using artificial neural networks and multivariate regression methods," Engineering Geology, vol. 131-132, pp. 11-18, 2012.

[25] V. N. S. Murthy, Geotechnical Engineering: Principles and Practices of Foundation Engineering, CRC Press, Boca Raton, Fla, USA, 2nd edition, 2009.

[26] E. S. Reddy and K. R. Sastri, Measurement of Engineering Properties of Soils, New Age International, New Delhi, India, 1st edition, 2002.

[27] "Method of test for soil for civil engineering purpose," BS 1377, British Standard Institute, London, UK, 1990.

[28] "Code of practice for site investigations," BS 5930, British Standard Institute, London, UK, 1999.

[29] B. M. Das, Principles of Geotechnical Engineering, Thomson Learning, Stamford, Conn, USA, 5th edition, 2001. 

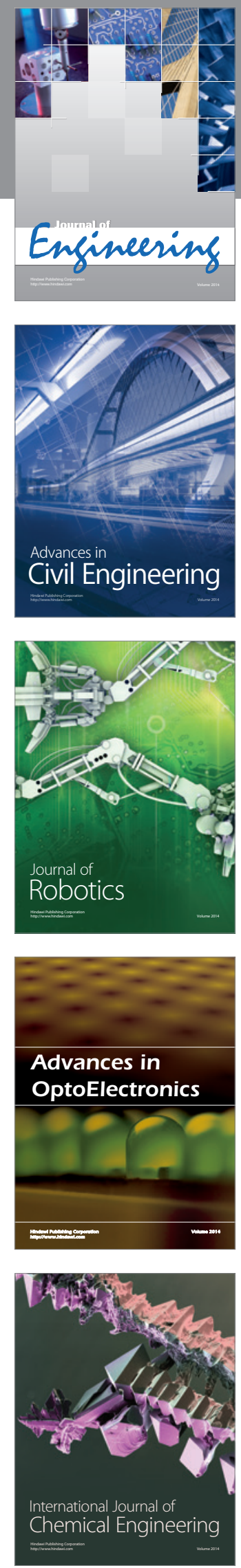

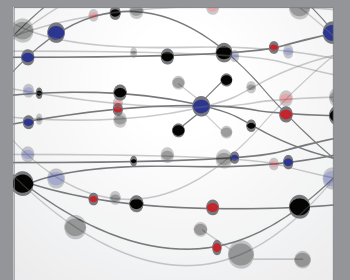

The Scientific World Journal
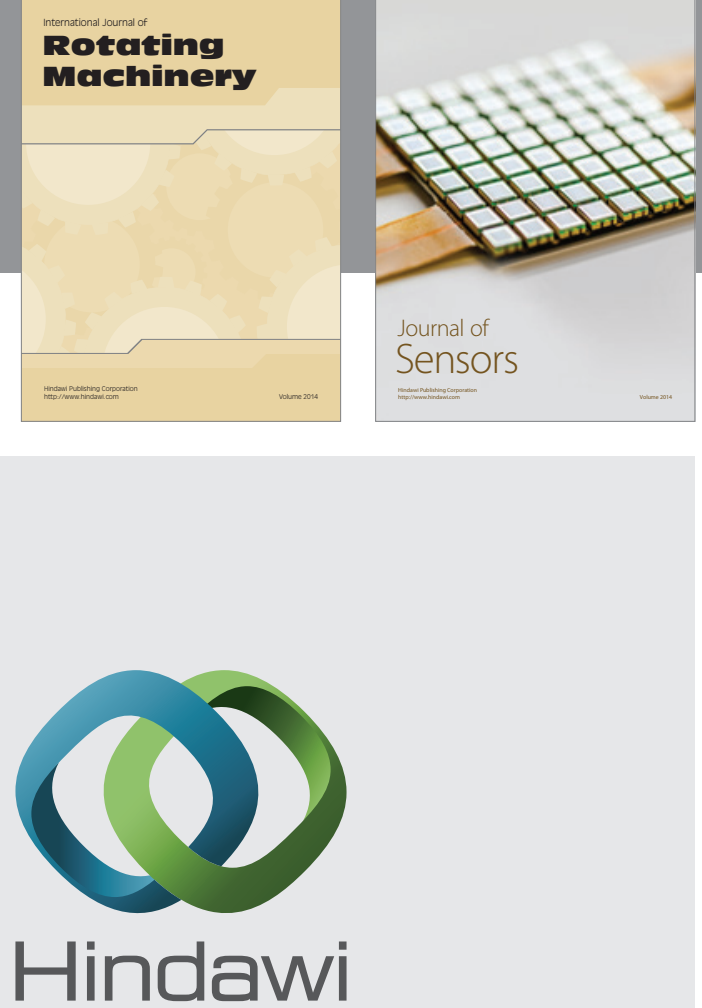

Submit your manuscripts at http://www.hindawi.com
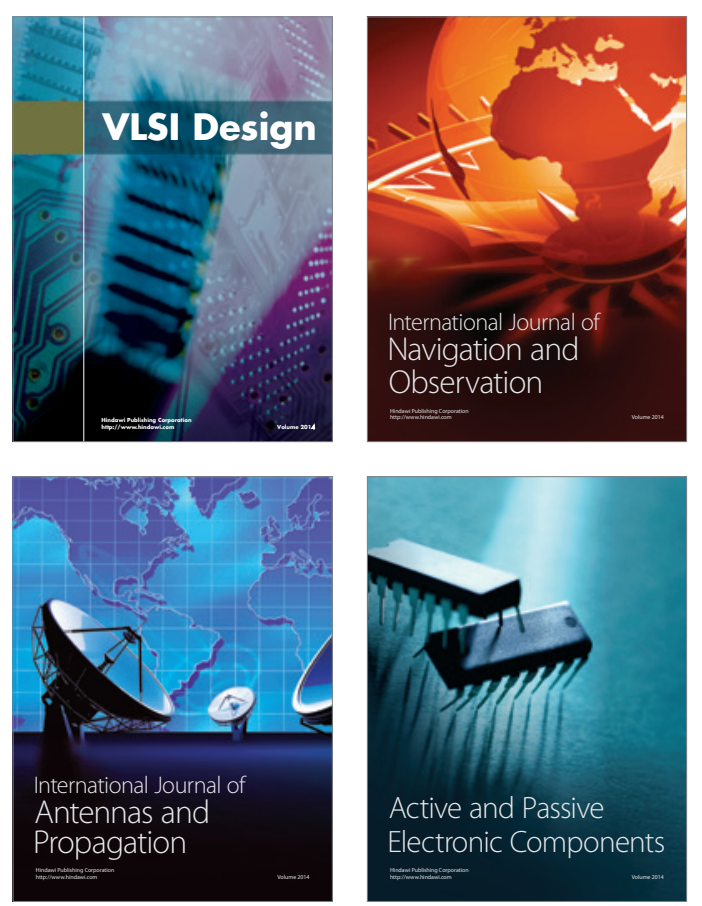
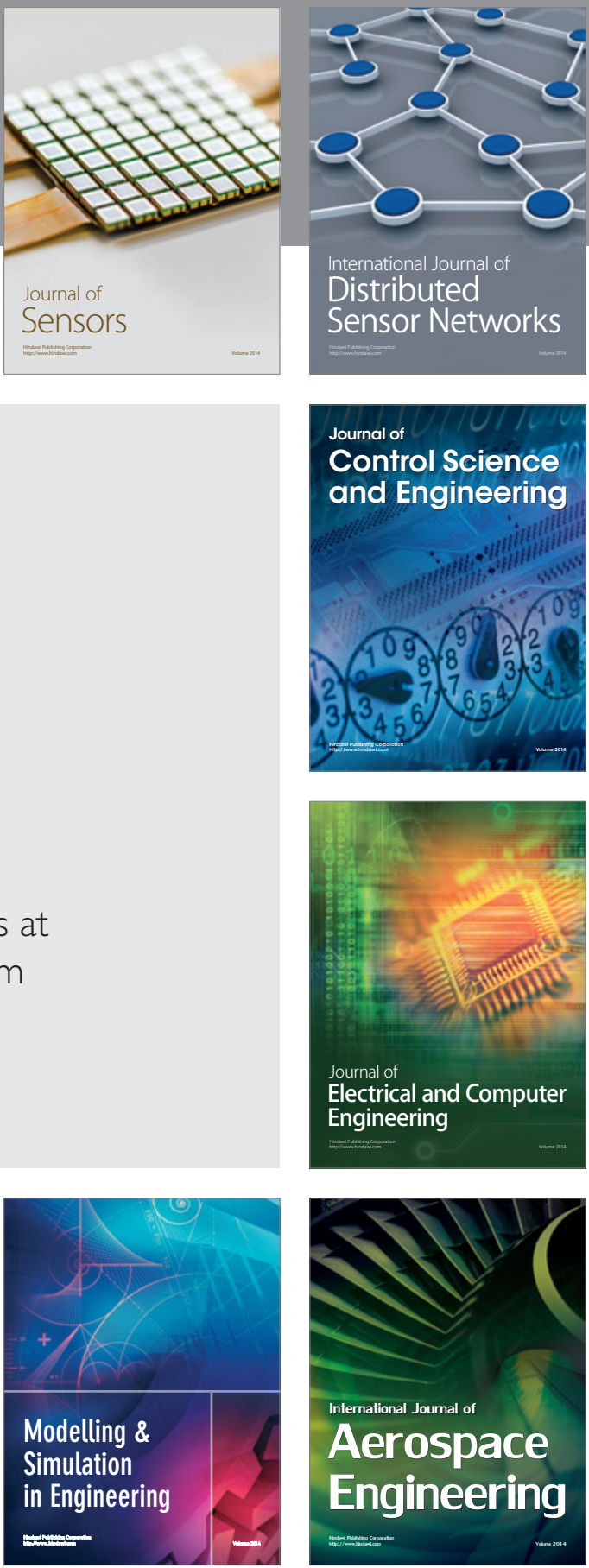

Journal of

Control Science

and Engineering
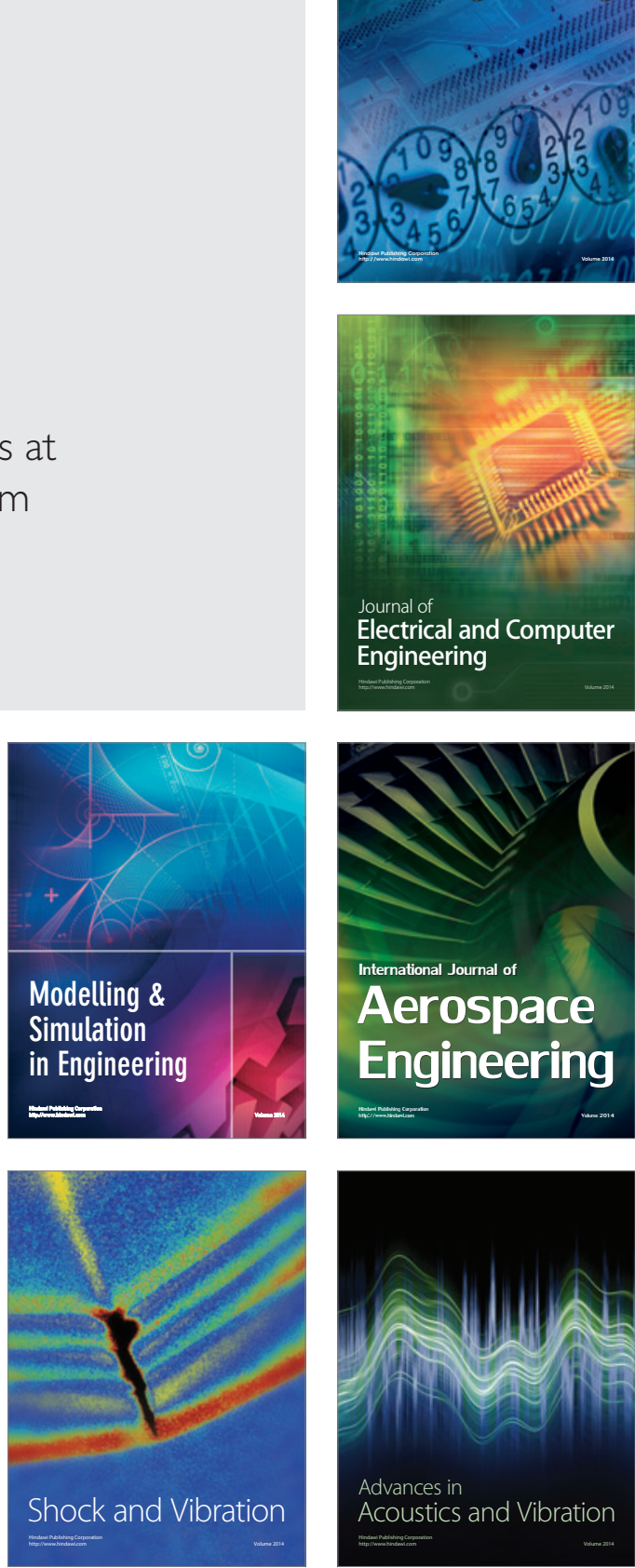